Published as Simons, M. (2017). The many encounters of Thomas Kuhn and French epistemology. Studies in History and Philosophy of Science, Studies in History and Philosophy of Science. http://dx.doi.org/10.1016/j.shpsa.2017.01.004

\title{
The Many Encounters of Thomas Kuhn and French Epistemology
}

Massimiliano SIMONS ${ }^{1}$

The reactions provoked by Thomas Kuhn's book, The structure of scientific revolutions [...] would provide high-quality experimental material for an empirical analysis of the ideologies of science and their relationship with their authors' positions in the scientific field. (Bourdieu, 1975: 38)

\section{Introduction}

It is an often stated fact that philosophy of science changed with the publication of Thomas Kuhn's The Structure of Scientific Revolutions (SSR) in 1962. This book has been considered the start of a 'historical turn' in philosophy of science. Followed by authors such as Imre Lakatos and Paul Feyerabend, the message was that, in order to do philosophy of science, one also needs to do history of science.

This was the case in Anglo-American philosophy of science, but in Continental Europe the situation was quite different. ${ }^{2}$ Especially in France, SSR was not seen as a revolution, but rather as a confirmation of what was already known. As Gary Gutting states, the "French could hardly share the excitement of what they rightly saw as old news." (Gutting, 2003: 46) Similarly, Ian Hacking claims that "Kuhn was a sensation for us, but rather old hat in France." (Hacking, 2002: 93) A historical approach, indeed, is the norm in French philosophy of science or 'French epistemology'. ${ }^{3}$ This is mainly due to the specific educational institutions in France, where history and philosophy of science were always closely linked, and students of philosophy were encouraged to combine the study of philosophy with that of a specific science (see Chimisso, 2008). Thus, authors such as Gaston Bachelard or Georges Canguilhem were already doing something very similar to Kuhn, namely trying to understand physics or biology by examining their specific historical developments.

\footnotetext{
1 KU Leuven, Institute of Philosophy (HIW), KU Leuven, Kardinaal Mercierplein 2, Box 3200, 3000 Leuven, Belgium Received 15 September 2016, Revised 17 December 2016, Accepted 13 January 2017, Available 2 online 7 February 2017. Massimiliano.simons@kuleuven.be

For the reception of SSR in Anglo-American philosophy, see Kindi \& Arabatzis (2012) and Richards \& Daston (2016).

3

In France the term 'epistemology' refers to philosophy of science. The term French epistemology is used here to distinguish it from 'historical epistemology,' which also includes authors such as Lorraine Daston or Hans-Jörg Rheinberger (see Hacking, 2002; Rheinberger, 2010).
} 
Published as Simons, M. (2017). The many encounters of Thomas Kuhn and French epistemology. Studies in History and Philosophy of Science, Studies in History and Philosophy of Science. http://dx.doi.org/10.1016/j.shpsa.2017.01.004

In this sense, one could claim that we are witnessing a synthesis between Continental and Anglo-American philosophy of science. Kuhn himself, for instance, states that

I suspect that anyone who believes that history may have deep philosophical import will have to learn to bridge the longstanding divide between the Continental and English-language philosophical traditions. (Kuhn, 1977: xv)

More recently, Anastasios Brenner has pointed at such a unification, first of all because Anglo-American philosophy has become more historical. "They reject the continuism [within the history of science] of the logical positivists, just as Bachelard and Koyré have rejected that of their predecessors." (Brenner, 2006: 115) $)^{4}$ Brenner speaks of a movement of "postpositivism' within analytic philosophy, which “could be seen as moving closer to historical epistemology." (Brenner, 2015: 210) ${ }^{5}$ At the same time, he notices how French epistemology has become more analytic and logical. Authors such as Jules Vuillemin or Gilles-Gaston Granger actively discussed, introduced and translated the work of authors such as Bertrand Russell, Ludwig Wittgenstein and W.V.O. Quine. ${ }^{6}$ Recent authors such as Hacking or HansJörg Rheinberger embody for Brenner this unification by actively combining both traditions.

Brenner argues that the divergence was historically caused by a cultural barrier, referring to such things as language or institutions (Brenner, 2015). Both traditions, according to him, share the same intellectual roots in discussions around the conventionalism of authors such as Henri Poincaré, who influenced both French epistemology and the Vienna Circle (Brenner, 2003). But since both sides are discovering one another, the dichotomy is disappearing. Rather we "may combine both methods: logically reconstructing the reasoning behind historical explanation, and submitting logic to historical inquiry.” (Brenner, 2015: 211)

Nevertheless, the situation is too complex to be described merely in terms of a cultural barrier. By focusing on the cultural differences, one tends to overlook the argumentative differences. Although there are signs of both traditions coming closer together, there are clear tensions as well. This article illustrates this tension by mapping the specific link between the work of

4

All French quotations are translated by the author, unless when referring to existing translations.

For a different history of 'post-positivism,' see Zammito (2004). Zammito is very critical of contemporary post-positivist programs within science studies, which were inspired by Quine and Kuhn, but resulted in indefensible postmodernism. However, he ignores this French tradition of post-positivism, which might offer a more viable alternative.

6 François Russo.

Other (and earlier) examples that Brenner does not mention are Robert Blanché, Jean Largeault or 
Published as Simons, M. (2017). The many encounters of Thomas Kuhn and French epistemology. Studies in History and Philosophy of Science, Studies in History and Philosophy of Science. http://dx.doi.org/10.1016/j.shpsa.2017.01.004

Thomas Kuhn and French epistemology, paying particular attention to his book SSR. This link will be explored in both directions. The first part will briefly examine the extent to which Kuhn was inspired by French epistemology. It will be argued that there is a connection here, but not with the most famous French epistemologists, such as Bachelard or Canguilhem.

More interesting and less explored is the influence in the opposite direction. The second part will therefore focus on how French epistemologists had discussed and evaluated SSR, focusing on authors such as Bachelard, Canguilhem, Foucault, Bourdieu and Althusser. There are three reasons why these reactions might be revealing. First of all, they can clarify the often debated and unclear position of Kuhn himself. Secondly, they give us a unique insight into the different approaches to philosophy of science. Finally, they can show the differences among French philosophers themselves. This will be done by confronting French epistemology with the work of more recent French authors, such as Bruno Latour and Isabelle Stengers. Based on these specific appreciations of SSR I will briefly suggest a typology of the different positions in philosophy of science.

\section{Was Kuhn inspired by French Epistemology?}

The influence of French epistemology on Kuhn has been the subject of previous studies. Garry Gutting, for instance, states that the "one movement in twentieth-century European thought that has substantive affinities with Kuhn's work is the French tradition of philosophy of science." (Gutting, 2003: 45) According to Gutting, Bachelard proposed a discontinuist reading of the history of science akin to Kuhn's and, similarly, Bachelard claimed that a scientific revolution results in a new worldview and new scientific norms (e.g. Bachelard, 2002). For Gutting, these authors cannot only be seen as a source of inspiration, but also as a possible correction of Kuhn's problems with relativism and incommensurability. Bachelard, in fact, proposed a philosophy which combines discontinuity and rationality, and thus evades certain forms of relativism.

Nevertheless, Kuhn himself rarely mentions Bachelard. In fact Kuhn mentions him only once, referring to Bachelard's thesis study on heat (Kuhn, 1977: 219n63; Bachelard, 1927). Only in a few interviews did he highlight his relation to Bachelard,stating for instance that "I did read some Bachelard. But it was so close to my own thought that I did not feel I had to read lots and lots more." (Kuhn, 1994: 160) In another, posthumous published interview, Kuhn recalls meeting Bachelard in Paris around 1950, an encounter that turned into a failure. With a letter of recommendation from Alexandre Koyré, he visited the apartment of Bachelard. "A large burly man in his undershirt came to the door, invited me in; I said, 'My French is bad, may we 
Published as Simons, M. (2017). The many encounters of Thomas Kuhn and French epistemology. Studies in History and Philosophy of Science, Studies in History and Philosophy of Science. http://dx.doi.org/10.1016/j.shpsa.2017.01.004

talk English?' No, he made me talk French. Well, this all didn't last very long." (Kuhn, 2000: $285)^{7}$ Although he thought that there were interesting similarities, and later read more of his work, Kuhn merely states that the framework of Bachelard is too constraining and too systematic.

Therefore, the claim of any influence of French epistemology on Kuhn becomes problematic. This assertion, however, is not only based on similarities in themes and ideas, but also on remarks by Kuhn himself. For instance, Kuhn states that "the early models of the sort of history that has so influenced me and my historical colleagues is the product of a postKantian European tradition which I and my philosophical colleagues continue to find opaque.” (Kuhn, 1977: xv)

But what authors did he have in mind? Besides Ernst Cassirer, he mainly mentions French epistemologists, but not Bachelard or Canguilhem. In the preface of SSR, for example, he refers to Alexandre Koyré, Émile Meyerson and Hélène Metzger. "More clearly than most other recent scholars, this group has shown what it was like to think scientifically in a period when the canons of scientific thought were very different from those current today." (Kuhn, 1970a: vi $)^{8}$ However, as the quotation above indicates, he sees these authors mainly as an inspiration for writing history of science, and not for their philosophical positions:

There have been philosophers of science, usually those with a vaguely neo-Kantian cast, from whom historians can still learn a great deal. I do urge my students to read Emile Meyerson and sometimes Léon Brunschvicg. But I recommend these authors for what they saw in historical materials not for their philosophies, which I join most of my contemporaries in rejecting. (Kuhn, 1977: 11)

Thus, the lessons for the new historiography of science did not arise from scientists nor historians. "Instead, they have come from philosophy, though mostly like Koyré, from Continental schools where the divide between history and philosophy is by no means so deep as in the English-speaking world." (Ibid.: 135) Indeed, for Kuhn Koyré deserves special credit as "the man who, more than any other historian, has been my maître" (Ibid.: 21) and whose

7

Kuhn also states that the "only thing of his I'd read [at that moment] was that Esquisse d'une Probleme Physique, I think it's called." (Kuhn, 2000: 284) The editors wrongly refer to the book La philosophie du non.

8

Other non-French authors he mentions are Butterfield, Cavell, Crombie, Dijksterhuis, Fleck, Lovejoy, Maier and Polanyi. I have, however, excluded them here from the discussion. The comparison with Fleck is made often, including by Kuhn himself. For a discussion, see Braunstein, (2003) and Mößner (2011). 
Published as Simons, M. (2017). The many encounters of Thomas Kuhn and French epistemology. Studies in History and Philosophy of Science, Studies in History and Philosophy of Science. http://dx.doi.org/10.1016/j.shpsa.2017.01.004

work "provide[d] the models which historians of science increasingly aimed to emulate. More than any other single scholar, Koyré was responsible for the first stage of the historiographical revolution.” (Kuhn, 1970b: 67)

Illuminating in this context is an encyclopedic article that Kuhn wrote about the history of science. Here he claims that there has been a historiographical revolution which, as stated above, he partly attributes to Koyré. In this article, however, he offers other reasons as well. First of all, he claims that historians of science have drawn lessons from the history of philosophy. Although he acknowledges the role of authors such as Cassirer, he states that partly it was learned from a small group of neo-Kantian epistemologists, particularly Brunschvicg and Meyerson, whose search for quasi-absolute categories of thought in older scientific ideas produced brilliant genetic analyses of concepts which the main tradition in the history of science has misunderstood or dismissed. (Kuhn, 1977: 108)

The new approach their work implied was that, rather than seeing the work of outdated science as irrational or deficient, they ascribe to it a different form of rationality, based on different categories of thought. Again, Koyré served as the perfect example for Kuhn. According to Koyré, one could only fully understand the scientific work of Galileo if one dived into the past and the context of the author. "That task, Koyré felt, could not be done without immersion in an entire corpus, that of Galileo and those of his immediate predecessors, contemporaries, and successors.” (Kuhn, 1970b: 67) In very similar terms he speaks of the work of Meyerson:

I didn't like the philosophy at all. But, boy, did I like the sorts of things he saw in historical material. He went into those briefly and I mean he didn't do it as a historian but he was getting it right in ways that were different from the ways that history of science was being written. (Kuhn, 2000: 287) ${ }^{9}$

Secondly, he attributes great importance to the work of the French epistemologist Pierre Duhem, which showed that one could not ignore medieval physics to understand Galileo's contributions. Finally, the failed attempts of authors such as Paul Tannery and George Sarton

9

According to Steve Fuller, it was the encounter with Meyerson that has "left the most indelible impression in Kuhn's intellectual orientation." (Fuller, 2000: 392) He argues that Meyerson and Kuhn share the idea that science is an autonomous practice with intrinsic ends, enclosed in its own paradigm. But the link Fuller tries to make is merely based on superficial resemblances and rather serves the goal of his book, namely showing how Kuhn made every critique on science impossible. Fuller makes similar debatable interpretations of the link with Koyré (60-70) and Bachelard (344), resulting in attempts to unmask their hidden agendas rather than attempts to understand the philosophical links. 
Published as Simons, M. (2017). The many encounters of Thomas Kuhn and French epistemology. Studies in History and Philosophy of Science, Studies in History and Philosophy of Science. http://dx.doi.org/10.1016/j.shpsa.2017.01.004

to constitute a general history of science had shown, according to Kuhn, that it is untenable to attribute contemporary distinctions to the past (Kuhn, 1977: 108-109).

However, this does not mean that Kuhn just repeated the work of French epistemologists. As stated above, he was very critical of their philosophical claims. Besides that, he also disagreed on numerous historiographical points. Kuhn was, for instance, critical of Koyré's "primacy of theoretical imagination over experience" (Kuhn, 1970b: 69). For Koyré, what was essential in the work of Galileo was not the experiments he did, but rather a completely new way of looking at the world, inspired by Platonism rather than Aristotelianism. Koyré rejected socioeconomical explanations of scientific change and the role of instruments. And although this might work for the case of Galileo, Kuhn thought that "it would have been a disaster" for cases such as chemistry or magnetism, because it would ignore "the learned world's new concern with the crafts, technology, and instrumentation." (Ibid.)

A range of other differences are pointed out by Brendan Lavror (2003). He states that Koyré starts from a stronger unity of thought: while for Koyré scientific theories are linked with contemporary philosophical and theological ideas, such as Platonism, for Kuhn the sciences are more independent of cultural history (see Kuhn, 1977: 118-119). Also, in the case of Koyré, just as for Bachelard or Brunschvicg, there is clear progress within the history of science, mainly because the history of science embodies a rational development. Kuhn, on the other hand, is far more reluctant to speak of progress between scientific paradigms. ${ }^{10}$

In relation to the problem of theoretical primacy, it is interesting to refer to the French epistemologist Hélène Metzger (see Melhado, 1990). She was a historian of science deeply influenced by Meyerson and Koyré. But in contrast with them, she mainly focused on the emergence of new scientific disciplines, such as chemistry during the $18^{\text {th }}$ and $19^{\text {th }}$ centuries, rather than on revolutions within 'old' sciences such as astronomy in the $17^{\text {th }}$ century (see Chimisso, 2001). Kuhn discovered Metzger's work when he was in France, around the time he met Bachelard (Kuhn, 2000: 287). She influenced Kuhn in several ways, including his claim that Stahl's chemistry is a mature scientific paradigm, rather than a form of prescience (see Metzger, 1974).

Kuhn's critique of the theoretical primacy in Koyré seems to follow the work of Metzger, who focuses more on the role of institutions and techniques in the $19^{\text {th }}$ century. However, that there is clear progress within the history of science (e.g. Brunschvicg, 1912). 
Published as Simons, M. (2017). The many encounters of Thomas Kuhn and French epistemology. Studies in History and Philosophy of Science, Studies in History and Philosophy of Science. http://dx.doi.org/10.1016/j.shpsa.2017.01.004

such a distinction is not found in the work of Kuhn. At least in SSR there is no clear distinction between the mechanism responsible for a revolution within a mature science (Koyré) and that responsible for the creation of a paradigm (Metzger) within a scientific field (although see Kuhn, 1976). Kuhn only focusses on mature sciences, while the process of maturation is hardly described. In this sense, he can be criticized for the same reason that he criticized Koyré: his model might work for some historical cases, but is rather problematic for others.

Based on this comparison, the relation between Kuhn and French epistemology is not very clear, since he has great reservations about their philosophies and there are some significant differences. Moreover, the main French epistemologists that he discussed are not the often mentioned Bachelard or Canguilhem, but lesser known figures such as Koyré or Metzger. The relation to the better known brands of French epistemology remains unclear. However, not only did Kuhn refer to French epistemologists; they also referred to him. Several French epistemologists, indeed, reacted to the publication of SSR. These reactions can tell us something more about the specific similarities and differences between them.

\section{How French epistemologists read Kuhn}

SSR was published in 1962 and republished in 1970 with an important postscript; only in 1972 was it translated into French. While it was still mainly ignored in the 1960s, it was this translation that sparked reactions in France. Although many of the more prominent French epistemologists reacted to SSR, the reaction was overall very negative. Authors such as Meyerson, Brunschvicg or Metzger had died several decades before its publication, but the tradition was still well-represented by authors such as Koyré, Bachelard, Canguilhem, Althusser or Foucault. It is helpful to look at what their perspective on Kuhn was. ${ }^{11}$

Koyré died in 1964, but apparently read the book in the final months of his life. Kuhn states that Koyré was very positive about the book and that he "reported from his sick-bed his pleasure in reading a book that seemed 'to fill the gap between the history of science as such and the social history that till now were miles apart'." (Kuhn, 1970b: 69) Only in later texts does Kuhn state that the book that Koyré had referred to was SSR (e.g. Kuhn, 2000: 286). Koyré rejected attempts to explain the progress of science through socioeconomic factors, but for him SSR opened the road for a reconciliation between internalist and externalist attempts to nuance their critiques and defend Kuhn's perspective. 
Published as Simons, M. (2017). The many encounters of Thomas Kuhn and French epistemology. Studies in History and Philosophy of Science, Studies in History and Philosophy of Science. http://dx.doi.org/10.1016/j.shpsa.2017.01.004

perspectives due to the intermediary notion of the paradigm. Socioeconomic elements might play a role in the history of science, but not as a direct influence on scientists. Rather they have an indirect effect through the formation of paradigms, while the development of science can simultaneously be a product of internal developments within the paradigm. We can infer this much on the basis of anecdotes that Kuhn recorded on several occasions, but the question remains of whether this faithfully represents Koyré's own perspective.

\subsection{BACHELARD AND HIS STUDENTS}

In the secondary literature parallels are often made between Bachelard and Kuhn (e.g. Danny, 1999). The main similarity is that of a discontinuist reading of the history of science, respectively conceptualized as an epistemological rupture or as a series of paradigm shifts. Bachelard himself died in 1962 and he did not live long enough to respond to Kuhn, but several of his students did. Authors such as Jean Largeault, Gilles-Gaston Granger and Jean Ladrière were, in contrast with such parallels, rather critical of SSR.

Largeault is very positive in his work about what he calls the 'idealism' of French epistemology, namely the idea that scientific facts are never mere brute facts, but are always marked by theory and rationality. However, authors such as Kuhn and Feyerabend "have turned this idealism into a nihilism" (Largeault, 1988: 14) due to the idea of the incommensurability of paradigms, which completely negates the rationality that was implied in this idealism. Incommensurability might be a good precaution for the individual historian to avoid anachronism, but it is inapplicable to scientific progress in its totality. "Incommensurability is valuable for individuals, but not for theories." Rather he calls it "at best a provocative paradox, perhaps a farce by epistemologists." (Largeault, 1984: 16-17)

Largeault also states that SSR does not work for logic or mathematics, where there is no form of incommensurability (Largeault, 1980: 121-122). It might work for physics, and he might accept that facts are not independent from theory but, apart from that, Largeault could not believe in radical breaks between paradigms because "the problem solved by every grand physical theory consists of the destruction of incompatibilities (between electromagnetism and mechanics : RR ; between RR and Newtonian gravity: RG ; between RG and quantum mechanics : etc.).” (Largeault, 1984: 17n41)

The same critique is present in the work of Granger and Ladrière. Both try to correct SSR by making a distinction between two forms of discontinuity. For instance, the Belgian philosopher Jean Ladrière, in his conclusion of a colloquium on SSR in 1973, offers some 
Published as Simons, M. (2017). The many encounters of Thomas Kuhn and French epistemology. Studies in History and Philosophy of Science, Studies in History and Philosophy of Science. http://dx.doi.org/10.1016/j.shpsa.2017.01.004

criticisms of the book. ${ }^{12}$ First of all, Ladrière argues that Kuhn overgeneralizes his schemes, as if there is only one structure for all scientific revolutions. Ladrière makes the analogy with biology: although one could state that all organisms follow biological laws, there is still a huge difference "between a starfish and a chimpanzee." (Ladrière, 1974: 175) Applied to the history of science this means that there is a difference between the structure of, for example, Galilean physics and quantum mechanics.

Secondly, SRR lacks the distinction "between two sorts of crises: on the one hand crises of constitution on the other hand crises of restructuration." (Ibid.) A crisis of constitution refers to the case which is discontinuous because one is faced with a completely new and different system:

The meaning of a crisis of constitution is in fact that, through it, thought succeeds for the first time in a certain domain to break with the living experience $[d u$ vécu] and to create a conceptual system capable of operating by itself and, if we may say, on itself. We are dealing here with an operation of detachment with relation to that which, in a certain vocabulary, can be called the natural experience. (Ibid.: 176)

On the other hand, the crisis of restructuration refers to a change due to logical problems or relations to other systems, both scientific and otherwise, around it. Because science in this case already surpassed natural or ordinary experience, there is no real discontinuity. There is rather a continuity of certain principles throughout these scientific changes. "One can say that once a science is really constituted, its development should be interpreted no longer by following a discontinuist scheme, but rather through a dialectical scheme.” (Ibid.: 177)

Echoing Ladrière, Granger distinguishes between external and internal discontinuities. An external discontinuity refers to the shift from pre-science to science, in which "the theme of incommensurability has meaning" (Granger, 1993: 107). However, Kuhn also applies this to internal discontinuities between paradigms within science. These internal variations, which Granger calls subparadigms (sous-paradigmes), are "products of internal discontinuities posterior to the formation of a common paradigm of all the scientific thought of the same object." (Ibid.) In this case there is no incommensurability, but rather a form of continuity. In this, both authors are clearly following Bachelard. Not only in the sense that they believe in scientific progress, but also when it comes to the double meaning of discontinuity. For an exception within French epistemology, a tradition to which he is also only partly linked. 
Published as Simons, M. (2017). The many encounters of Thomas Kuhn and French epistemology. Studies in History and Philosophy of Science, Studies in History and Philosophy of Science. http://dx.doi.org/10.1016/j.shpsa.2017.01.004

Bachelard, an epistemological rupture does not only refer to historical breaks between different stages of science, but also to the break between ordinary and scientific thought. According to Bachelard, the mind is naturally tempted by certain images, such as seeing heat as a hidden substance in the object (cf. Bachelard, 1927). Science can only progress by breaking with them. For Bachelard "it must therefore be accepted that there is a very real break between sensory knowledge and scientific knowledge." (Bachelard, 2002: 237) It is this form of discontinuity that French epistemologists may call incommensurable, but discontinuities between mature scientific theories will always show some form of continuity.

\subsection{CANGUILHEM AND FouCAULT}

Perhaps with the exception of Bachelard, the most popular parallel within secondary literature is that between Kuhn and Foucault (e.g. Dreyfus \& Rabinow, 1982). Both French and foreign authors, indeed, make this parallel (e.g. Piaget, 1974: 122). ${ }^{13}$ On the other hand, several authors have criticized these parallels stating that there are clear differences (e.g. Kusch, 1991: 86-109). Giorgio Agamben, for example, states that "this proximity was not the effect of an actual affinity but the result of a certain confusion" in the early works of Foucault (Agamben, 2009: 14).

Foucault himself rarely discusses the work of Kuhn and appears to have actively distanced himself from it. ${ }^{14}$ However, when George Steiner, in a review of Foucault, asked the French author why he did not refer to SSR in spite of the clear similarities between the two of them, Foucault responded:

Mr. Steiner believes that I should have cited Kuhn. It is true that I hold Kuhn's work to be admirable and definitive. [...] When I read Kuhn's book during the winter of 196364 (I believe it was a year after its publication), I had just finished writing The Order of Things. I thus did not cite Kuhn, but quoted instead from the historian of science who shaped and inspired his thoughts: G. Canguilhem. (Foucault, 1971: 60)

It is indeed only in the introduction to the English translation of The normal and the pathological of Canguilhem that Foucault mentions Kuhn again. Here Foucault tries to

Piaget is an interesting case, because Kuhn was inspired by Piaget, whom he discovered in a footnote in the work of R.K. Merton (Kuhn, 2000: 279).

14

The same goes for the relation the other way around. Kuhn rarely refers to Foucault, for instance only in a footnote (Kuhn, 2000: 14). Kuhn, however, also criticizes Foucault because he "is scarcely interested in the processes by which [the] system [he describes] is led to transform itself" (quoted in Delaporte, 1998: 296; see also Kuhn, 1994: 160-161). 
Published as Simons, M. (2017). The many encounters of Thomas Kuhn and French epistemology. Studies in History and Philosophy of Science, Studies in History and Philosophy of Science. http://dx.doi.org/10.1016/j.shpsa.2017.01.004

distance Canguilhem from Kuhn by claiming that, in French epistemology, there is a certain normativity within the history of science

and this norm cannot be identified with a theoretical structure or an actual paradigm because today's scientific truth is only an episode of it - let us say provisionally at most. It is not, by depending on a 'normal science' in T.S. Kuhn's sense that one can return to the past and validly trace its history: it is in rediscovering the 'norm' process, the actual knowledge of which is only one moment of it, without one being able, save for prophesying, to predict the future. (Foucault, 1989: Xv)

The claim that the history and philosophy of science requires a specific normativity is indeed present in the work of Canguilhem, and also in his own critique of Kuhn. For Canguilhem there is a clear difference between Bachelard and Kuhn, stating that "Kuhn is mistaken about the nature of scientific rationality as such." (Canguilhem, 1988: 13) The ground for Canguilhem's critique is the normativity towards which Foucault hints. For Canguilhem, Kuhn is still confused by the legacy of logical positivism and unable to "join the rationalist camp". The concepts of paradigm and normal science

presuppose intentionality and regulation, and as such they imply the possibility of a break with established rules and procedures. Kuhn would have them play this role without granting them the means to do so, for he regards them as simple cultural facts. For him, a paradigm is the result of a choice by its users. Normal science is defined by the practice in a given period of a group of specialists in a university research setting. Instead of concepts of philosophical critique, we are dealing with mere social psychology. (Ibid.: 13)

In the case of Bachelard or Jean Cavaillès, in contrast, it is always a question of normed science, and not normal science. There is a rational regulation of scientific discontinuity that Kuhn is unable to conceptualize.

However, Canguilhem is very brief in his critique and hardly refers to Kuhn in his other work. Instead, he attributes his critique to someone else, namely the forgotten French epistemologist François Russo, who similarly argues that "Kuhn [...] minimizes the role of rationality in the progress of science. This is one of the principle weaknesses of his work." (Russo, 1974a: 626n13) Russo was a student of Bachelard and Canguilhem, and wrote several studies on the history and philosophy of science, in which he criticized Kuhn.

Russo's starting point is the idea that the history of science must be complemented by a historical epistemology. While 'phenomenological' history of science might focus on historical facts, the epistemological branch must focus on the underlying attitudes, 
Published as Simons, M. (2017). The many encounters of Thomas Kuhn and French epistemology. Studies in History and Philosophy of Science, Studies in History and Philosophy of Science. http://dx.doi.org/10.1016/j.shpsa.2017.01.004

motivations and reasons of scientific progress (Russo, 1974a: 621). This epistemological point of view is itself inspired by Bachelard and Canguilhem, namely by the principle that one should start from the norms of contemporary science to evaluate how the history of science is still scientifically relevant for present science. Or, as Canguilhem states, "one should place oneself in a normative point of view if one wants to judge the efficacy of a thought." (Canguilhem, 1968: 178) For Russo SSR is clearly part of the first discipline, and it therefore lacks an eye for the epistemological questions (Russo, 1974b: 347).

In his work, Russo makes many of the same critiques as earlier discussed authors, such as the lack of a distinction between the formation of a first paradigm and a scientific revolution within a scientific discipline (Russo, 1983: 95). However, he also adds some new elements. Firstly, he makes the distinction between epistemological paradigms, which concern their object of study, and methodological paradigms, which concern the instruments and methods of science (Russo, 1974b: 355); and a related distinction between simple and complex paradigms, e.g. the principle of inertia versus Newtonian mechanics. Such complex paradigms, then, consist of a range of simple paradigms, although they are more than the sum of their parts (Russo, 1983: 97).

Secondly, he criticizes SSR for not making a clear distinction between the different stages of a scientific revolution, namely between the negative and the positive moment. The negative moment refers to the abandonment of a paradigm, while the positive moment implies both the creation of a new paradigm and the creation of new knowledge within itself (Russo, 1974b: 359-360). Such a distinction allows for claims such as the claim that the creation of Newton's paradigm did not destroy the paradigm of Descartes, and that the two might exist next to each other (Russo, 1983: 99).

Thirdly, he warns that a fixation on scientific revolutions creates a blind eye for other forms of knowledge production, for instance the construction of a paradigm itself. But one also forgets "the emergence of new horizons, outside of the scope of normal science, but of which the knowledge that they bring forth appear to be compatible with normal science, at least for a certain time." (Russo, 1974b: 352) As examples he refers to the fields opened by microscopes, $\mathrm{x}$-rays or radioactivity.

Finally, he criticizes SSR for seeing paradigms as independent of each other and of their object. Every paradigm is for Russo always related to a specific field of phenomena, e.g. that of electricity, mechanics, etc. (Russo, 1974b: 352n2). Canguilhem borrows this critique when he warns that Bachelard's notion of an epistemological rupture originated in a specific 
Published as Simons, M. (2017). The many encounters of Thomas Kuhn and French epistemology. Studies in History and Philosophy of Science, Studies in History and Philosophy of Science. http://dx.doi.org/10.1016/j.shpsa.2017.01.004

context, namely that of mathematics and contemporary chemistry. Kuhn makes the mistake of extending it "to other areas of the history of science without a good deal of reflection about the specific nature of the area to be studied." (Canguilhem, 1988: 14)

Besides these corrections on SSR, Russo also claims that Kuhn lacks a theory of how existing knowledge gets integrated within a new paradigm. In this sense Russo is very critical towards the notion of incommensurability, because for him there are clear elements of continuity as well (Russo, 1974a: 640n33). This continuity possesses a structure that Kuhn ignores. "Contrary to its title, The Structure of Scientific Revolutions, the work of Kuhn does not pay attention to the structure of new knowledge connections" between successive paradigms (Russo, 1974b: 362n1). As an example he gives the 'astronomical revolution', which implied a whole range of paradigm shifts that are linked together: the shift from geocentrism to heliocentrism, the abandonment of the idea that planets are incorruptible, the abandonment of circles for ellipses (Kepler), and finally the idea of general attraction (Newton). Moreover, there are several different forms of paradigm shifts: one paradigm might fight off the old one, or they may both be rejected for, or even integrated in, a third one (e.g. wave and particle theories). Paradigms, thus, cannot be considered as completely separate from each other, but are rationally and normatively linked. This normativity is, according to Russo and Canguilhem, impossible to grasp in Kuhn's terminology.

\subsection{BOURDIEU AND AlthusSER}

As already illustrated by the case of Foucault, the influence of Bachelard and Canguilhem is also present in the work of various political philosophers, including Pierre Bourdieu or Louis Althusser. In the case of Bourdieu it is mainly within his sociology of the scientific field, in which Bourdieu situates himself, that Kuhn is mentioned and contrasted with French epistemology: :

And I did not cease to look to Bachelard and the French tradition of epistemology, in my effort to found an epistemology of the social sciences on a constructivist philosophy of science (which anticipated Kuhn but without turning purely and simply into the relativism of the postmodernists), as much as in my analysis of the scientific field. (Bourdieu, 2004: 106)

Bourdieu thus wants to avoid any form of relativism, while defending a clear idea of progress and objectivity for science, by focusing on "the problem posed by the historical genesis of supposedly trans-historical truths" (Ibid.: 1). In this context, he sharply criticizes other philosophies and sociologies of science, such as SSR. He recognizes that Kuhn has introduced 
Published as Simons, M. (2017). The many encounters of Thomas Kuhn and French epistemology. Studies in History and Philosophy of Science, Studies in History and Philosophy of Science. http://dx.doi.org/10.1016/j.shpsa.2017.01.004

the idea of discontinuity in the Anglo-American context as well as the notion that science is a collective endeavor, based on a paradigm (Ibid.: 14). Kuhn is described as a scholar who discovers the idea of the Kantian a priori, but in a relativized way. In this sense SSR is a book "whose theses contain little that is radically new, at least for readers of Bachelard, who was the object of similar manoeuvres at much the same time, in a different tradition." (Bourdieu, 1975: 46n53)

Although Kuhn makes these analogous claims, he is still heavily criticized by Bourdieu, both from his Marxist and from his epistemological perspective. The 'functionalism' Kuhn shares with authors such as R.K. Merton is unacceptable for Bourdieu: Kuhn sees the scientific field as focused around a range of shared norms and rules, the paradigm, that scientists impose on themselves. The problem is that, because of this, there is no consideration for the role of struggle and competition, and therefore Kuhn lacks "a coherent model for exploring change" (Bourdieu, 2004: 15).Bourdieu's proposal is that we see the scientific field as a permanent struggle for field-specific capital, e.g. citations and recognition by other actors within the field. In this sense the scientific field is relatively autonomous from the rest of society, but not free from struggle:

If we are not to fall back into the idealist philosophy which credits science with the power to develop in accordance with its immanent logic (as Kuhn still does when he suggests that 'scientific revolutions' occur only as a result of exhaustion of the 'paradigms') we must posit that investments are organized by reference to - conscious or unconscious anticipation of the average chances of profit." (Bourdieu, 1975: 22)

It is this social dimension that creates a dynamic of the scientific field that eventually leads to objectivity. Not because of some specific norms or a priori method, but rather because the new actors entering the field tend to be their "most rigorous and vigorous competitors, the most competent and the most critical, those therefore most inclined and most able to give their critique full force" (Bourdieu, 2004: 54). In this sense, the objectivity of scientific truth is almost a mere side-effect of this internal logic. The same goes for scientific revolutions. Rather than following a "strictly internalist representation of change" (Ibid.: 16) as in SSR, Bourdieu sees revolutions as a product of actors in the field refusing to follow the existing cycles of recognition. Instead they create new cycles which open the path for accumulating new forms of symbolic capital (Bourdieu, 1975: 24).

In the case of Bourdieu there are some clearly Marxist elements mixed in the critique addressed to Kuhn, but this is even more clear in the Althusserian school. Althusser was a 
Published as Simons, M. (2017). The many encounters of Thomas Kuhn and French epistemology. Studies in History and Philosophy of Science, Studies in History and Philosophy of Science. http://dx.doi.org/10.1016/j.shpsa.2017.01.004

student of Bachelard, who borrowed his concept of an epistemological break and applyied it to Marx (Althusser, 1965). The comparison between Althusser and Kuhn is therefore often made in secondary literature (e.g. Smith, 1984). However, Althusser himself never discussed Kuhn. Students of him, such as Étienne Balibar and Dominique Lecourt, on the other hand, do criticize SSR extensively.

It is interesting to note that both Balibar and Lecourt only discuss Kuhn in their texts about the relation between Althusser and Bachelard. Both start from the fact that several "commentators have seen a 'convergence' if not an identity pure and simple of the epistemological positions defended by Althusser and by Kuhn." (Lecourt, 1975: 9 ; Balibar, 1991: 34-35) Preceding the reflections by Brenner by 40 years, Lecourt wonders whether this can be read as a sign of a "postponed encounter" between "two parallel epistemological traditions: have they not both, from either side, reached results which coincide, at least in part, in their latest representatives?" For Lecourt, there are indeed some clear similarities: both propose discontinuist readings of the history of science, both pay attention to the role of "the scientific division of labour and its material instances: books, manuals, scientific instruments, the constitution of groups of investigators, etc.", and both speak about the role of norms (Lecourt, 1975: 10).

However, Lecourt's answer to that proposed view is firmly negative: there is no encounter between Althusser and Kuhn. All the above mentioned similarities are merely superficial: a common discontinuist perspective is not enough, it matters what kind of discontinuity one has in mind to determine one's position within the field of history of science. Or as Balibar states:

Kuhn does only break, in appearance, with the idea of a history of progressive accumulation, a pure 'quantitative' history, to confirm it massively in the framework of what he calls 'normal science', of which he says that it is the essential object of his work (Balibar, 1991: 54).

According to Balibar, Kuhn only uses his notion of discontinuity to affirm at the same time a conservative image of science as solving puzzles within strict rules. In a way similar to Ladrière, he states that SSR sticks with a fixed structure of scientific revolutions which stays invariant, while Althusser and Bachelard are more open to changes within the structure of this transition, depending on the specific context and science (Ibid.: 35).

The second problem they address is similar to Canguilhem's. The notion of 'normal' science seems to imply a form of normativity, which is however unclear. For Kuhn, normal science seems to refer to a range of shared beliefs and practices by a group of scientists who will also 
Published as Simons, M. (2017). The many encounters of Thomas Kuhn and French epistemology. Studies in History and Philosophy of Science, Studies in History and Philosophy of Science. http://dx.doi.org/10.1016/j.shpsa.2017.01.004

defend them. Furthermore, Lecourt asks, to "what normativity does normal science conform?" (Lecourt, 1975: 16) At first sight it seems to refer to a choice made by the scientists between the different paradigms, but echoing the critiques made by Feyerabend or Watkins, this does not distinguish science from criminal gangs or theology (see Lakatos \& Musgrave, 1970). The analogy of the Gestalt switch, which Kuhn uses in this context, is also deeply problematic according to Lecourt. For a Gestalt switch is not a choice, but is forced upon us, so the question of what drives scientific change remains unanswered. If such a switch is no analogy, then it is a mere image or a claim of identity. If it is an image, it should be refuted for being unclear, and if it is a claim that scientific change works in an identical way, then the history of science becomes an object for psychology. According to Lecourt, such a view would lead to a theory of fixed categories of the human mind. In this sense, what looked like a conventionalism of Kantian categories is actually some form of apriorism. "Scratch a conventionalist and you will find an apriorist." (Lecourt, 1975: 18)

We thus see that, for Lecourt, the question of scientific change remains open. And it is exactly around this question of scientific change that the critique of many of these French epistemologists centers. Similarly to Largeault, Granger and Ladrière, Balibar and Lecourt have a different form of discontinuity in mind, namely a rational one. For Balibar this is linked with the notion of irreversibility: for authors such as Bachelard, discontinuities imply a point of no return. For Kuhn, on the other hand, paradigms seem completely separate from each other, without any connection or even displaying a relation of incommensurability (Balibar, 1991: 56). French epistemology tries to develop a form of discontinuity or historical change that remains rational. Many French epistemologists subscribe to a claim by Jean Cavaillès in his most famous work, stating that

one of the essential problems of the doctrine of science is that, in fact, progress itself may not be augmentation of volume by juxtaposition, in which the prior subsists with the new, but a continuous revision of contents by deepening and eradication. What comes after is more than what existed before, not because it contains it or even because it prolongs it, but because it necessarily departs from it and carries in its content, every time in a unique way, the mark of its superiority. There is more consciousness in it - and it is not the same consciousness. (Cavaillès, 1960: 78)

This is what Largeault had in mind when he praises the 'idealism' of French epistemology, Bourdieu when he speaks of the historical genesis of trans-historical truths, or Balibar when 
Published as Simons, M. (2017). The many encounters of Thomas Kuhn and French epistemology. Studies in History and Philosophy of Science, Studies in History and Philosophy of Science. http://dx.doi.org/10.1016/j.shpsa.2017.01.004

he states that his perspective goes "beyond the alternative between history and truth: it is true in its own history" (Balibar, 1994: 159).

However, it is not always clear what such a rational discontinuity entails . Within French epistemology this is often linked with the claim that it is not the individual that is the subject of this rational progress, but rather the dialectics of the concept or the scientific field. For them the rationality within science can only be guaranteed if it lies on something that escapes the vagaries of the individual subject. And even if this specific paradox between history and rationality is not yet fully elaborated within the work of French epistemologists, "they at least make this ultimate paradox formulable with which the [epistemological] break confronts us." (Ibid.: 161) What they understand as Kuhn's thesis of incommensurable paradigms negates this paradoxical nature of science, and must therefore be dismissed.

\section{A new wave of French philosophy of science}

To grasp the difference between Kuhn and French epistemology, it is also helpful to refer to an article by Geof Bowker and Bruno Latour (1987) that aims to contrast French epistemology with sociology of science. They argue that, although both traditions start from a critique of positivism and empiricism, they do so on completely different grounds. Facts on their own can never be enough, but what must be added differs for both traditions. Starting from the idea of underdetermination associated with authors such as Quine and Duhem, in sociology of science this was seen "as a proof that we must turn to society; whereas in French epistemology Duhem's argument has been taken as proof of the need to turn to theory" (Ibid.: 722). Societal norms, class interest or political ideologies cannot explain why certain scientific facts are accepted, but rather the theories that frame these facts and the normativity of its progress.

According to the authors it was Koyré who "vaccinated a generation of French historians against social explanations of science: by making them accept the influence of philosophy and theology on science, he prevented infection from the influence of society." (Ibid.: 723) Nevertheless, French epistemologists are not proponents of a form of Whiggish history, where the history of science is seen as one accumulating struggle towards more rationality and truth. This is shown clearly by their focus on the discontinuity in the history of science and their explicit criticism, as is also the case for Kuhn (e.g. Kuhn, 1970b). However, at the same time French epistemologists are not merely anti-Whiggish, because science is still seen as a rational practice, and any attempt to debunk the rationality of science is fiercely criticized by them. In this sense, the authors describe French epistemology as anti-anti-Whiggish, because 
Published as Simons, M. (2017). The many encounters of Thomas Kuhn and French epistemology. Studies in History and Philosophy of Science, Studies in History and Philosophy of Science. http://dx.doi.org/10.1016/j.shpsa.2017.01.004

they still "seek to ensure that mere historians do not water down the radical newness of science.” (Bowker \& Latour, 1987: 725)

This can then be applied to the case of Kuhn: many saw similarities due to common ideas such as the existence of scientific ruptures or the thesis that facts can never decide by themselves, but need something more. French epistemologists, however, might see Kuhn not as part of traditional analytic philosophy of science nor as one of their own, but as part of sociology of science. It is indeed true that sociologists of science were the early adaptors of Kuhn's work (e.g. Barnes, 1982) and that analytic philosophers criticized him for reducing philosophy of science to sociology and psychology (see Lakatos \& Musgrave, 1970). Therefore his work is seen as separated from the search for the rationality of science and must be criticized.

That this distinction is at stake is also shown by contrasting the reception of SSR by French epistemology with that of more recent French philosophers of science, who actively distance themselves from authors such as Bachelard or Canguilhem. One such example is mentioned by Bowker \& Latour (1987: 730), namely that of Michel Serres. It is indeed telling that Serres uses Kuhn's work in a rather positive way (e.g. Serres, 1980: 86, 138, 145). The only echo within his work of the earlier mentioned critiques is that Kuhn's perspective was not so new, but "was rather almost contemporary to the birth of this discipline called the history of science", namely in the work of Auguste Comte (Serres, 1977: 127).

\subsection{LATOUR AND STENGERS}

Other representatives are Latour himself and Isabelle Stengers. Latour's own view on Kuhn is ambiguous, in the sense that he tends to be positive and negative about Kuhn for the same reasons. He praises Kuhn's concept of paradigm because it bridges the gap between the cognitive and the social, the explicit and the implicit aspects of science (Callon \& Latour, 1991: 18). However, when he speaks about the case of Ludwik Fleck, who he sees as a predecessor of his own approach, he diagnoses SSR as a relapse in all the old errors of the externalist point of view and as a misinterpretation of Fleck (Latour, 2002). Yet this critique has nothing in common with that of French epistemology. Latour's ambiguity is rather a product of a similar ambiguity that he demonstrates towards sociology of science in general. Although he situates himself in the sociological camp, he criticizes sociology of science for reducing everything to the social. For Latour, external and internal explanations are two sides of the same coin and have to be rejected in order to open the path for a third position that avoids the pitfalls of both (see Latour, 1992). 
Published as Simons, M. (2017). The many encounters of Thomas Kuhn and French epistemology. Studies in History and Philosophy of Science, Studies in History and Philosophy of Science. http://dx.doi.org/10.1016/j.shpsa.2017.01.004

This is also the case for Isabelle Stengers. Similarly to Serres, she is rather positive about SSR and uses its insights occasionally (e.g. Stengers, 1997: 109-120). Nevertheless, Stengers has some criticisms. For instance, she states that Kuhn sees this structure of scientific revolutions as something natural, rather than as a specific historical way to do science. "To describe the life of the sciences as a natural phenomenon is to say that there is only one choice, either to hamper them or to give them the means to continue." (Stengers, 2000: 53) As authors such as Ladrière or Balibar already suggested, this structure of science is a contingent historical fact, not a necessity. But for Stengers this is not only a question of a wrong interpretation of the past, but also of the future. In her work with Ilya Prigogine, she states that by generalizing this scheme one implicitly favors one type of science over others:

In this view the driving force behind scientific innovation is the intensely conservative behavior of scientific communities, which stubbornly apply to nature the same techniques, the same concepts, and always end up by encountering on equally stubborn resistance from nature. [....] Thus scientists have to deal with crises imposed upon them against their will. (Prigogine \& Stengers, 1984: 309)

They themselves want to stress other aspects of science. For the aim of Prigogine was to conceptualize a different way of doing physics yet this was not based on a specific crisis nor against his will. Rather "the recent history of science is also characterized by a series of problems that are the consequences of deliberative and lucid questions asked by scientists who knew that the questions had both scientific and philosophical aspects." (Ibid.) Scientists are not doomed to be puzzle solving sleepwalkers within normal science.

Stengers' main interest in Kuhn, however, arises from the observation that many scientists reacted positively to SSR, while for many philosophers it was a scandal. According to Stengers, there are two reasons for Kuhn's popularity among the scientists. First of all, SSR preserves "the autonomy of the scientific community in relation to its political and social environment." (Stengers, 2000: 6) In this sense the picture is drawn that science can only work if one leaves the internal working of the paradigm alone, otherwise one would be killing the goose with the golden eggs. The second reason is that Kuhn also constructs an intrinsic link "between this autonomy and the impossibility of reducing the paradigm to a sociological or psychological reading." (Ibid.: 49) Thus for her, contrary to the critiques of analytic philosophy and French epistemology, Kuhn actually shows that a paradigm is something that could not be reduced to social psychology. However, at the same time, echoing this third 
Published as Simons, M. (2017). The many encounters of Thomas Kuhn and French epistemology. Studies in History and Philosophy of Science, Studies in History and Philosophy of Science. http://dx.doi.org/10.1016/j.shpsa.2017.01.004

position of Latour, she contradicts the interpretation of the sociologists, since they tend to reduce a paradigm to social categories.

It all depends on how one interprets the notion of a paradigm. For Stengers, but also for Latour (2006: 27-30), a

paradigm, first and foremost, is of a practical order. What is transmitted is not a vision of the world but a way of doing, a way not only of judging phenomena, of giving them a theoretical signification, but also of intervening. (Stengers, 2000: 49)

The idea is that a paradigm enables scientists to create a new type of relation with the world itself, which does not leave the world unchanged. Rather it intervenes within the world and gives it a new mode of existence, namely as a scientific fact, i.e. a fact that can be clearly defined and reproduced before colleagues. This is why Kuhn speaks about puzzles and why for Kuhn "science is not made of ideas" (Latour, 2006: 29). The creation of such a relation is not pre-given nor a pure psychological decision, but rather the product of an inexplicable 'event', when scientist and phenomena succeed in changing their behavior in a form they can both agree on.

What this implies is clear when one contrasts Kuhn's perspective with that of Lakatos. For Stengers Lakatos' perspective "inspires the idea of a gathering of facts that can be defined independently of the theory, so that one can then compare and negotiate between the facts and the theory." (Stengers, 2000: 49) Kuhn opposes this perspective with his notion of incommensurability. The core of this notion, for Stengers, is not that it implies that scientists are chained by their paradigm to interpret the same facts in different ways. "This misunderstanding stems from the fact that the notion of the paradigm corresponds not to a new version of the 'impregnation' of facts by theories, but to the notion of the invention of facts." (Ibid: 50) One should abandon the idea of a brute fact, and realize that the main definition of a fact "is not to be observable but to constitute active productions of observability, which requires and presuppose the paradigmatic language." (Ibid) What Kuhn does in SSR is to show that the history of science is not about a search for more facts with which we should create a relation of knowledge. Rather, his core idea is that the relations to the objects have a history as well.

\section{Conclusion}

This article sketched the many encounters between French epistemology and Thomas Kuhn. From this it is clear that the relation between the two is far more complex than is often portrayed. The first part made clear that although he was inspired by French epistemology, 
Published as Simons, M. (2017). The many encounters of Thomas Kuhn and French epistemology. Studies in History and Philosophy of Science, Studies in History and Philosophy of Science. http://dx.doi.org/10.1016/j.shpsa.2017.01.004

Kuhn seldom referred to its most prominent authors. Rather he took his inspiration from lesser known figures, such as Meyerson or Metzger. Secondly, even in relation to these authors he remained very critical, especially concerning their philosophical positions.

The second, and more extensive part of this article showed that many French epistemologists replied to SSR in a highly critical way. Not only famous philosophers such as Foucault, Canguilhem or Bourdieu were examined, but also lesser known ones, such as Ladrière, Russo or Lecourt. In their work there was a clear consensus about Kuhn. SRR has a similarity with their work because it problematizes the traditional analytic philosophy of science that aims for an a-temporal criteria for science. However, at the same time, they fundamentally disagreed with what they saw as Kuhn's alternative for this.

This indicates that French epistemology starts from a specific view on science. Their problem with SSR is related to two aspects. Firstly, the idea of discontinuity and incommensurability. Many French epistemologists rejected the incommensurability thesis, at least for discontinuities within mature science, while accepting it for the discontinuity between ordinary and scientific knowledge. Secondly, they disagreed on the element of normativity and rationality. In this sense, they came close to authors such as Popper or Lakatos. Nevertheless there is a crucial difference. Rather than stating that there is an a-temporal norm for sciencificity, for French epistemology the rationality and normativity of science lies within its historical process. This is the central paradox of many of their reflections, namely how to combine a science that is both rational and has a history and thus novelty.

French epistemologists associated Kuhn with a third position, namely that of a sociological approach or what can be called social constructivism. Such a reading is itself problematized by a new generation of French philosophers of science, such as Latour or Stengers. They are far more positive about Kuhn, but mainly by claiming that his work can be seen as something that is neither the position of traditional analytic philosophy of science, nor French epistemology, nor social constructivism. They develop another perspective, which can be called 'French neoconstructivism'. This perspective draws its lessons from social constructivism, but also actively distances itself from it. Although paradigms are related to socioeconomic factors, they cannot be reduced to them or must at least be understood in a completely different way. In this sense it sees itself as a correction of social constructivism and it mobilizes Kuhn for this purpose. He is praised to the extent that he transcended the other positions, but criticized for elements that still come close to it. 
Published as Simons, M. (2017). The many encounters of Thomas Kuhn and French epistemology. Studies in History and Philosophy of Science, Studies in History and Philosophy of Science. http://dx.doi.org/10.1016/j.shpsa.2017.01.004

However, Kuhn's position in this story is very unclear and he seems to be the victim of several approaches trying to mobilize or criticize him for their own gain. Often this problem is framed as the choice between him being either a follower of analytic philosophy, similar to Lakatos or Larry Laudan, or part of a more social constructivist program (e.g. Zammito, 2004). Taking this French tradition into account, however, adds a new dimension to this discussion. Kuhn's work can, in fact, be used to distill the typology of the different positions sketched above: analytic philosophy of science, French epistemology, social constructivism and French neoconstructivism. In which category Kuhn falls is unclear: the first two positions tend to distance themselves from his work, while the latter two tend to recruit him. In the context of this article, this leads to two final reflections. One the one hand we can ask to what extent Kuhn is really marked by a sociological approach, as seems to follow from the perspective of Bowker \& Latour (1987). Can he really be recruited for social constructivism or is there rather a fundamental affinity to French philosophy of science? If so, this opens to path for Kuhn's SSR being part of a third path, neither seeking for absolute, a-temporal rationalist criteria nor giving a purely sociological account of science. And secondly, if Kuhn was born in France, would his terminology or his claims have been different? Is he really an adversary for French epistemology or rather a misunderstood friend?

\section{Funding}

This work was supported by the Research Foundation - Flanders (FWO).

\section{Acknowledgements}

I have to acknowledge Paul Cortois for the many discussions and feedback about earlier drafts of this article. Also I would like to thank Samuel O'Connor Perks, Laura Katherine Smith, Jonathan Sholl, and the two anonymous reviewers for their useful comments.

\section{References}

Althusser, L. (1965). Pour Marx. Paris: Maspero.

Agamben, G. (2009). The signature of all things: On method. New York: Zone books.

Bachelard, G. (1927). Etude sur l'évolution d'un problème de physique : La propagation thermique dans les solides. Paris: Vrin.

Bachelard, G. (2002). The Formation of the Scientific Mind - A Contribution to a Psychoanalysis of Objective Knowledge. Manchester: Clinamen Press.

Balibar, E. (1991). Ecrits pour Althusser. Paris: La Découverte. 
Published as Simons, M. (2017). The many encounters of Thomas Kuhn and French epistemology. Studies in History and Philosophy of Science, Studies in History and Philosophy of Science. http://dx.doi.org/10.1016/j.shpsa.2017.01.004

Balibar, E. (1994). Lieux et noms de la vérité. La Tour d'Aigues: Ed. de l'Aube.

Barnes, B. (1982). T. S. Kuhn and social science. London: Macmillan.

Bourdieu, P. (1975). The specificity of the scientific field and the social conditions of the progress of reason. Social Science Information, 14, 19-47.

Bourdieu, P. (2004). Science of science and reflexivity. Cambridge: Polity press.

Bowker, G., \& Latour, B. (1987). A Booming Discipline Short of Discipline: (Social) Studies of Science in France. Social Studies of Science, 17(4), 715-748.

Braunstein, J.-F. (2003). Thomas Kuhn lecteur de Ludwik Fleck. Archives De Philosophie, (3), 403-422.

Brenner, A. (2003). Les origines françaises de la philosophie des sciences. PUF : Paris.

Brenner, A. (2006). Quelle épistémologie historique ?: Kuhn, Feyerabend, Hacking et l'école bachelardienne. Revue De Métaphysique Et De Morale, 49(1), 113-125.

Brenner, A. (2015). Is There a Cultural Barrier Between Historical Epistemology and Analytic Philosophy of Science? International Studies in the Philosophy of Science, 29(2), 201-214.

Brunschvicg, L. (1912). Les étapes de la philosophie mathématique. Paris: Alcan.

Callon, M., \& Latour, B. (1991). La science telle qu'elle se fait : Anthologie de la sociologie des sciences de langue anglaise. Paris: La Découverte.

Canguilhem, G. (1968). Études d'histoire et de philosophie des sciences. Paris: Vrin.

Canguilhem, G. (1988). Ideology and rationality in the history of the life sciences. Cambridge, MA: MIT press.

Cavaillès, J. (1960). Sur la logique et la théorie de la science, PUF, Paris.

Chimisso, C. (2001). Hélène Metzger: the history of science between the study of mentalities and total history. Studies in History and Philosophy of Science, 32(2), 203-241.

Chimisso, C. (2008). Writing the history of the mind: Philosophy and science in France, 1900 to 1960s. Aldershot: Ashgate.

Danny, L. (1999). Historical and Constructivist Philosophies of Science: Kuhn, Bachelard and Canguilhem. Hong Kong: University of Hong Kong Libraries.

Delaporte, F. (1998). Foucault, epistemology and history. Economy and Society, 27(2-3), 285297.

Dreyfus, H. \& Rabinow, P. (1982). Michel Foucault : Beyond structuralism and hermeneutics. Brighton: Harvester press.

Foucault, M. (1971). Foucault responds 2. Diacritics I, 2: 60. 
Published as Simons, M. (2017). The many encounters of Thomas Kuhn and French epistemology. Studies in History and Philosophy of Science, Studies in History and Philosophy of Science. http://dx.doi.org/10.1016/j.shpsa.2017.01.004

Foucault, M. (1989). Introduction. In Canguilhem, G. The Normal and the Pathological (pp. 8-24). New York: Zone Books.

Fuller, S. (2000). Thomas Kuhn : A philosophical history for our times. Chicago (Ill.): University of Chicago press.

Hacking, I. (2002). Historical ontology. Cambridge (Mass.): Harvard university press.

Granger, G. (1993). La science et les sciences. Paris: PUF.

Gutting, G. (2003). Thomas Kuhn and French philosophy of science. In Thomas Nickels (ed.). Thomas Kuhn (pp. 45-64). Cambridge: Cambridge University Press.

Kindi, V., \& Arabatzis, T. (2012). Kuhn's The structure of scientific revolutions revisited. London: Routledge.

Kuhn, T. (1970a). The structure of scientific revolutions. Chicago (Ill.): University of Chicago press.

Kuhn, T. (1970b). Alexandre Koyré and the History of Science: on an Intellectual Revolution. Encounter, 34: 67-69.

Kuhn, T. (1976). Mathematical vs. Experimental Traditions in the Development of Physical Science. The Journal of Interdisciplinary History, 7(1), 1-31.

Kuhn, T. (1977). The essential tension : Selected studies in scientific tradition and change. Chicago (Ill.): University of Chicago press.

Kuhn, T. (1994). Paradigms of Scientific Evolution: Thomas S. Kuhn. In Borradori, G. The American philosopher: Conversations with Quine, Davidson, Putnam, Nozick, Danto, Rorty, Cavell, MacIntyre, and Kuhn (pp. 153-167). Chicago (Ill.): University of Chicago press.

Kuhn, T. (2000). The road since structure : Philosophical essays, 1970-1993 with An autobiographical interview. Chicago (Ill.): University of Chicago press.

Kusch, M. (1991). Foucault's strata and fields : An investigation into archaeological and genealogical science studies. Dordrecht: Kluwer.

Ladrière, J. (1974). Exposé de synthèse. In Berleur, J. \& Fourez, G. Méthodes scientifiques et problèmes réels (pp. 168-195). Namur: Presses universitaires de Namur.

Lakatos, I., Musgrave, Alan (eds.). (1970). Criticism and the growth of knowledge. London: Cambridge university press.

Largeault, J. (1980). Énigmes et controverses : Quelques problèmes en théorie de la connaissance. Paris: Aubier Montaigne.

Largeault, J. (1984). Philosophie de la nature 1984. Val-de-Marne: Université Paris XII.

Largeault, J. (1988). Principes classiques d'interprétation de la nature. Paris: Vrin. 
Published as Simons, M. (2017). The many encounters of Thomas Kuhn and French epistemology. Studies in History and Philosophy of Science, Studies in History and Philosophy of Science. http://dx.doi.org/10.1016/j.shpsa.2017.01.004

Lavror, B. (2003). Why did Kuhn's Structure of scientific revolutions cause a fuss? Studies in History and Philosophy of Science, 34(2), 369-390.

Latour, B. (1992). One More Turn after the Social Turn : Easing Science Studies into the Non-Modern World. In McMullin, E. The Social Dimensions of Science (pp. 272-292). Notre Dame: Notre Dame University Press.

Latour, B. (2002). Transmettre la syphilis, partager l'objectivité. In Fleck, L. (2005). Genèse et développement d'un fait scientifique. Paris: Les Belles Lettres.

Latour, B. (2006). Chroniques d'un amateur de sciences. Paris: Presses de Mines.

Lecourt, D. (1975). Marxism and epistemology : Bachelard, Canguilhem and Foucault. London: NLB.

Melhado, Evan M. (1990). Metzger, Kuhn, and eighteenth-century disciplinary history. In Freudenthal, G.. Etudes sur Hélène Metzger/Studies on Hélène Metzger (pp. 111-134). Leiden: Brill.

Metzger, H. (1974). Newton, Stahl, Boerhaave et la doctrine chimique. Paris: Blanchard.

Mößner, N. (2011). Thought styles and paradigms - a comparative study of Ludwik Fleck and Thomas S. Kuhn. Studies in History and Philosophy of Science, 42(2), 362-371.

Piaget, J. (1974). Le structuralisme. Paris: PUF.

Prigogine, I. \& Stengers, I. (1984). Order out of chaos : Man's new dialogue with nature. London: Fontana paperbacks.

Richards, R. \& Daston, L. (2016). Kuhn's Structure of Scientific Revolutions at fifty: Reflections on a science classic. Chicago: University of Chicago Press.

Rheinberger, H.-J. (2010). On historicizing epistemology: An essay. Stanford: Stanford university press.

Russo, F. (1974a). Epistémologie et histoire des sciences. Archives de philosophie, 37(4), 617-657.

Russo, F. (1974b). Typologie du progrès des connaissances scientifiques. Première Partie. Revue des questions scientifiques, 315-363.

Russo, F. (1983). Nature et méthode de l'histoire des sciences. Paris: Blanchard.

Serres, M. (1977). Hermès. IV : La distribution. Paris: Ed. de Minuit.

Serres, M. (1980). Hermès. V : Le passage du nord-ouest. Paris: Ed. de Minuit.

Smith, S. (1984). Reading Althusser : An essay on structural marxism. Ithaca (N.Y.): Cornell university press. 
Published as Simons, M. (2017). The many encounters of Thomas Kuhn and French epistemology. Studies in History and Philosophy of Science, Studies in History and Philosophy of Science. http://dx.doi.org/10.1016/j.shpsa.2017.01.004

Stengers, I. (1997). Power and invention: situating science. Minneapolis (Minn.): University of Minnesota press.

Stengers, I. (2000). The invention of modern science. Minneapolis: University of Minnesota press.

Zammito, J. (2004). A nice derangement of epistemes: Post-positivism in the study of science from Quine to Latour. Chicago (Ill.): University of Chicago press. 